\title{
APLIKASI TEKNOLOGI FERMENTASI DALAM PENGEMBANGAN USAHA PUPUK BIOORGANIK DI DESA PUPUAN TEGALLALANG GIANYAR BALI
}

\author{
N.G.K. Roni ${ }^{1}$, P. Dyatmikawathi ${ }^{2}$, N.K. Seminari ${ }^{3}$, dan N.W. Siti ${ }^{4}$
}

\begin{abstract}
ABSTRAK
Kegiatan pengabdian kepada masyarakat ini bertujuan untuk alih teknologi fermentasi dalam pengembangan usaha pupuk bioorganik untuk menunjang pertanian organik di Desa Pupuan, Kecamatan Tegallalang, Kabupaten Gianyar. Metode yang diterapkan dalam pemberdayaan masyarakat pada kegiatan IbW adalah sebagai berikut: (1) Kordinasi dan komunikasi secara partisipasif dengan kelompok ternak pengelola pemelihara sapi perbibitan untuk merumuskan program mulai dari perencanaan, operasional dan evaluasi; (2) Penyuluhan untuk membangun persepsi dan pemahaman masyarakat mengenai inovasi atau program yang diterapkan; (3) Pelatihan dan simulasi mengenai terapan ipeks yang dialihkan bagi masyarakat; (4) Pendampingan yaitu pertemuan secara berkala dan berkelanjutan antara pendamping dengan masyarakat sasaran hingga ipteks yang dialihkan dapat dilaksanakan secara mandiri oleh masyarakat. Hasil yang diperoleh menunjukkan bahwa Kegiatan desiminasi ipteks melalui program IbW di Desa Pupuan, Kecamatan Tegallalang, Kabupaten Gianyar dapat berlangsung dengan baik yang ditunjukkan dengan adanya partisipasi aktif dan daya adopsi ipteks yang tinggi. Partisipasi aktif mitra dalam seluruh kegiatan desiminasi teknologi cukup tinggi, yaitu kehadiran anggota kelompok pada saat penyuluhan dan pelatihan mencapai $92 \%$, yang bertanya/mengemukakan pendapat $65 \%$, dan ikut mencoba praktek $61 \%$. Kemampuan adopsi ipteks dan inisiatif mitra untuk memproduksi produk secara mandiri cukup tinggi, sebesar $65 \%$.
\end{abstract}

Kata Kunci : teknologi fermentasi, usaha pupuk bioorganik, limbah pertanian

\begin{abstract}
Activities aimed at transferring fermentation technology for the development of bioorganic fertilizer business to support organic farming in Pupuan Village, Tegallalang District, Gianyar Regency. The methods applied in the community empowerment of IbW activities are as follows: (1) Participatory coordination and communication with livestock breeding management groups to formulate programs ranging from planning, operation and evaluation; (2) Counseling to build community perceptions and understanding of innovations or programs implemented; (3) Training and simulation of applied ipeks transferred to the community; (4) Assistance is regular and continuous meetings between assistants with target communities to transferred science and technology can be implemented independently by the community. The results show that the IIMD dissemination activities through the IbW program in Pupuan Village, Tegallalang District, Gianyar Regency can be well implemented as indicated by the active participation and high adoption of science and technology. The active participation of partners in all technological dissemination activities is quite high, ie the presence of group members at counseling and training reaches $92 \%$, who ask / express $65 \%$ opinion, and join $61 \%$ practice try. The ability to adopt science and partner initiatives to produce products independently is high, at $65 \%$.
\end{abstract}

Keywords : technology of fermentation, business, bio-organic fertilizer, agricultural waste

${ }^{1}$ Staf Pengajar Fakultas Peternakan Universitas Udayana, gustironi@unud.ac.id

${ }^{2}$ Staf Pengajar Universitas Dwijendra

${ }^{3}$ Staf Pengajar Fakultas Ekonomi dan Bisnis Universitas Udayana

${ }^{4}$ Staf Pengajar Fakultas Peternakan Universitas Udayana, wayansiti@unud.ac.id 


\section{PENDAHULUAN}

Desa Kedisan dan Pupuan merupakan dua dari tujuh desa yang ada di Kecamatan Tegallalang kabupaten Ginyar, terletak pada daerah dataran tinggi, dengan ketinggian lebih dari $418-750 \mathrm{~m}$ di atas permukaan laut (dpl) curah hujan $2.249 \mathrm{ml} / \mathrm{th}$. . Karena letaknya pada dataran tinggi, maka udaranya segar dan bersih dengan suhu yang sejuk. Kedua wilayah desa tersebut merupakan kawasan subur dengan sumber air yang mencukupi. Disamping itu, panorama alamnya sangat indah dengan view lembah sungai dan terasering persawaan sehingga selain untuk pertanian juga cocok untuk tempat peristirahatan atau tujuan wisata.

Penggunaan lahan di Desa Kedisan dan Pupuan didominasi oleh lahan pertanian yang mencapai 87 $\%$. Begitu pula dengan mata pencaharian penduduk lebih dari $73 \%$ berasal dari sektor pertanian (pertanian lahan sawah, perkebunan, dan peternakan). Hal ini mengindikasikan bahwa sektor pertanian merupakan bidang startegis sehingga perlu medapatkan prioritas. Lahan pertanian yang cukup luas di desa Kedisan dan Pupuan merupakan mata pencaharian utama bagi sebagian besar penduduk di desa tersebut, yang meliputi berbagai komuditi terutama padi sawah, jeruk, jahe, pepaya, dan berbagai komuditi lainnya. Untuk menunjang pengembangan komuditi tersebut sebagian besar petani mengandalkan pupuk anorganik secara terus menerus dalam jangka waktu yang lama sehingga dapat berdampak kurang baik terhadap kualitas tanah secara fisik, kimia maupun biologinya. Hal ini sudah mulai nampak dari sangat menurunnya bahkan tidak ada lagi jenis-jenis biota tanah tertentu yang hidup terutama di lahan sawah seperti capung dan lintah yang sebelumnya keberadaannya sangat banyak.

Kebijakan pemerintah provinsi Bali untuk kembali ke pertanian organik merupakan suatu terobosan yang diharapkan dapat mengatasi menurunnya kualitas tanah pertanian dan mencegah kerusakan yang lebih parah, di samping untuk meningkatkan pendapatan peternak. Program tersebut salah satunya direalisasikan dengan pemberian pupuk organik bersubsidi kepada anggota subak yang ada di wilayah Bali.Untuk menunjang program tersebut dan untuk meningkatkan pendapatan peternak perlu dikembangkan usaha pupuk bioorganik, namun penguasaan ipteks oleh masyarakat sasaran masih terbatas. Mengatasi hal tersebut perlu dilakukan penyuluhan, pelatihan dan pendampingan terhadap petani peternak agar dapat meningkatkan pengetahuan dan keterampilan tentang pengembangan usaha pupuk bioorganik

\section{METODE PELAKSANAAN}

Metode yang diterapkan dalam pemberdayaan masyarakat pada kegiatan IbW adalah sebagai berikut: (1) Penyuluhan untuk membangun persepsi dan pemahaman masyarakat mengenai inovasi atau program yang diterapkan, (2) Pelatihan dan simulasi mengenai terapan ipeks yang dialihkan bagi masyarakat, dan (3) Pendampingan yaitu pertemuan secara berkala dan berkelanjutan antara pendamping dengan masyarakat sasaran hingga ipteks yang dialihkan dapat dilaksanakan secara mandiri oleh masyarakat

\section{Tahap kegiatan}

Pelaksananan kegiatan alih teknologi fermentasi untuk pengembangan usaha pupuk bioorganik untuk menunjang pertanian organik adalah sebagai berikut :

(1) Kordinasi dan komunikasi secara partisipasif dengan masyarakat sasaran untuk merumuskan program mulai dari perencanaan, operasional dan evaluasi

(2) Penyuluhan tentang pentingnya teknologi budidaya ternak sapi, pemanfaatan limbah untuk pakan dan aplikasi teknologi fermentasi untuk menjamin ketersediaan pakan yang

\section{2 | BULETIN UDAYANA MENGABDI}


mencukupi kebutuhan dan pengolahan kotoran sapi yang dihasilkan untuk pengembangan usaha pupuk bioorganik.

(3) Pelatihan penggunanaan teknologi fermentasi untuk pengembangan usaha pupuk bioorganik

Pembuatan demplot dan pendampingan pengembangan usaha pupuk bioorganik melalui bimbingan teknis secara berkala dengan kelompok peternak dan pemberian konsultasi menyangkut solusi dari berbagai persoalan terkait dengan aplikasi teknologi tersebut..

\section{HASIL DAN PEMBAHASAN}

Kegiatan ini dilaksanakan di kelompok ternak Pucak Mesari yang beranggotakan 25 orang di desa Pupuan, Tegallalang, Gianyar. Desiminasi teknologi dilaksanakan melalui kegiatan kooedinasi dan persiapan materi, kegiatan penyuluhan dan pelatihan singkat selama 1 hari yang dipusatkan di kandang mitra, serta kegiatan pendampingan melalui pembentukan demoplot di kelompok ternak mitra. Ipteks yang didesiminasikan di mitra adalah teknologi produksi pupuk bioorganik dengan teknologi fermentasi menggunakan turunan fermentor yang dibuat oleh peternak hasil pendampingan dari pelatihan program IbW tahun sebelumnya, pelatihan teknik pengemasan pupuk, rancang bangun pengemas pupuk dan uji kandungan hara pupuk bioorganik produksi mitra. Evaluasi kegiatan dilakukan pada setiap sub-kegiatan melalui; 1) Evaluasi tingkat partisivasi mitra, 2) Evaluasi penguasan/daya adopsi Iptek, dan 3) Evaluasi kemampuan membuat produk Ipteks secara mandiri.

Bahan baku pupuk bioorganik terdiri dari kotoran ternak (feces sapi) (Gambar 3.1), serbuk gergaji kayu, abu dan fermentor. Komposisi masing-masing material tersebut disajikan pada Tabel 3.1. Pelaksanaan kegiatan pada mitra dapat berjalan dengan baik dan dengan peran serta mitra yang cukup tinggi (Tabel 2), adapun kegiatan penyuluhan dan pelatihan singkat yang dipusatkan di areal kandang mitra diikuti oleh $92 \%$ anggota mitra dan pada kegiatan tersebut $65 \%$ anggota mitra mengajukan pertanyaan/mengemukakan pendapat terkait pembuatan turunan fermentor, teknik fermentasi, teknik pengemasan pupuk. Saat kegiatan pelatihan, $65 \%$ anggota mitra ikut membantu produksi pupuk bioorganik. Kegiatan demoplot pelatihan teknologi produksi dan pengemasan pupuk bioorganik juga dapat berlangsung dengan baik (Gambar 3.2). Pada saat pendampingan beberapa anggota kelompok juga memproduksi produk secara mandiri. Berdasarkan hasil pengamatan diketahui $60 \%$ mitra telah mampu memproduksi produk secara mandiri (Tabel 3.2).

Tabel 3.1. Formula Pupuk Bioorganik Yang Diproduksi Dengan Teknologi Fermentasi

\begin{tabular}{|r|l|c|}
\hline \multicolumn{1}{|c|}{ No } & \multicolumn{1}{|c|}{ Bahan Pupuk bioorganik } & Jumlah \\
\hline 1 & Kotoran Ternak (Feses Sapi) (kg) & 60 \\
\hline 2 & Serbuk Gergaji Kayu (kg) & 20 \\
\hline 3 & Abu (kg) Total (kg) & 8 \\
\hline 4 & Fermentor (liter) & 2 \\
\hline & & $\mathbf{1 0 0}$ \\
\hline & Starter/Fermentor $\quad$ Tumlah (liter) \\
\hline 1 & Starter (liter) & 1 \\
\hline 2 & Molases (liter) $\quad$ Total Larutan fermentor & 1 \\
\hline 3 & Air (liter) & $\mathbf{2 0}$ \\
\hline
\end{tabular}


Tabel 3.2 Partisipasi Mitra dalam Kegiatan IbW

\begin{tabular}{|l|l|c|c|}
\hline No & \multicolumn{1}{|c|}{ Kegiatan } & Jumlah & \% \\
\hline A & Kegiatan Pelatihan & 23 & 92 \\
\hline 1 & Absensi/Kehadiran & 15 & 65 \\
\hline 2 & Mengajukan pertanyaan/pendapat & 14 & 61 \\
\hline 3 & Ikut mencoba & & \\
\hline B & \multicolumn{1}{|c|}{\begin{tabular}{l} 
Kegiatan Demoplot \\
\hline 1
\end{tabular}} & $\begin{array}{l}\text { Membantu produksi dan pengemasan produk } \\
\text { (pupuk bioorganik) }\end{array}$ & 20 \\
\hline 2 & $\begin{array}{l}\text { Memproduksi dan mengemas pupuk bioorganik } \\
\text { secara mandiri }\end{array}$ & 65 \\
\hline
\end{tabular}

Berdasarkan Tabel 3.2 diketahui rataan partisipasi aktif mitra pada seluruh sub kegiatan adalah $74 \%$, sedangkan inisiatif untuk memproduksi produk pupuk bioorganik adalah sebesar $65 \%$. Tingginya partisipasi dan daya adopsi ipteks mitra juga tercermin dari kualitas pupuk yang dihasilkan yang dapat diihat berdasarkan analisis kandungan hara pupuk tersebut. Tingginya kandungan nutrien/hara produk yang dihasilkan mitra (Tabel 3.3) menunjukkan daya adopsi ipteks mitra yang cukup tinggi dan keberhasilan pelaksanaan kegiatan desiminasi teknologi pada mitra. Hal ini kemungkinan disebabkan oleh adanya kemauan dan partisipasi aktif mitra yang tinggi dalam seluruh sub-kegiatan serta adanya kesadaran mitra akan pentingnya teknologi yang didesiminasikan. Disamping itu teknologi yang didesiminasikan merupakan teknologi tepat guna yang relatif murah dan mudah diaplikasikan oleh masyarakat termasuk oleh petani-peternak.

Tabel 3.3 Kandungan Hara Pupuk Organik Mitra Hasil Pelaksanaan IbW

\begin{tabular}{|l|l|c|c|c|}
\hline \multicolumn{2}{|c|}{ Komponen Hara } & $\begin{array}{c}\text { Kandungan } \\
\text { Hara }\end{array}$ & Standar SNI ${ }^{2}$ & Keterangan \\
\hline 1 & $\mathrm{pH}$ & 8,6 & $6,80-7,49$ & agak alkalis \\
\hline 2 & Kadar Air (\%) & 25,68 & maks. 50\% & Baik \\
\hline 3 & C-organik (\%) & 18,51 & $9,8-32 \%$ & Cukup \\
\hline 4 & N total (\%) & 0,64 & min. 0,4\% & Baik \\
\hline 5 & P tersedia (ppm) & 461,18 & min. 0,1\% & kurang \\
\hline 6 & K tersedia (ppm) & 15419,70 & min. $0,2 \%$ & cukup \\
\hline
\end{tabular}

Keterangan: ${ }^{1)}$ Hasil analisis Lab. Tanah Fakultas Pertanian UNUD, ${ }^{2}$ Standar Kualitas Kompos SNI 19-7030-2004

Keberhasilan adopsi teknologi produksi pupuk bioorganik telah memberikan manfaat yang sangat besar bagi mitra, yang mengakui sangat terbantu dengan adanya teknologi tersebut khususnya dalam hal kemudahan yang mereka rasakan dalam memperoleh pupuk organik. Pengolahan kotoran ternak menjadi pupuk organik telah memberikan sumber penghasilan tambahan bagi mitra, disamping areal kandang ternak menjadi lebih bersih dan sehat. Mitra juga mengaku bahwa merasa terbantu dalam hal mempercepat produksi pupuk dalam jumlah besar sehingga berani menerima order pupuk lebih banyak Disamping itu pemanfaatan limbah sebagai pupuk organik secara tidak langsung telah mampu mengurangi resiko negatif keberadaan limbah bagi lingkungan khususnya terkait pencemaran lingkungan yang dapat ditimbulkannya, sehingga dapat membantu terwujudnya pembangunan yang berwawasan lingkungan.

\section{KESIMPULAN DAN SARAN}

1. Kegiatan desiminasi ipteks melalui program IbW di Desa Pupuan, Kecamtan Tegallalang, kabupaten Gianyar dapat berlangsung dengan baik yang ditunjukkan dengan adanya partisipasi aktif dan daya adopsi ipteks yang tinggi.

\section{4 | BULETIN UDAYANA MENGABDI}


2. Partisipasi aktif mitra dalam seluruh kegiatan desiminasi teknologi cukup tinggi, yaitu sebesar $74 \%$

3. Kemampuan adopsi ipteks dan inisiatif mitra untuk memproduksi produk secara mandiri cukup tinggi, yaitu sebesar $60 \%$.

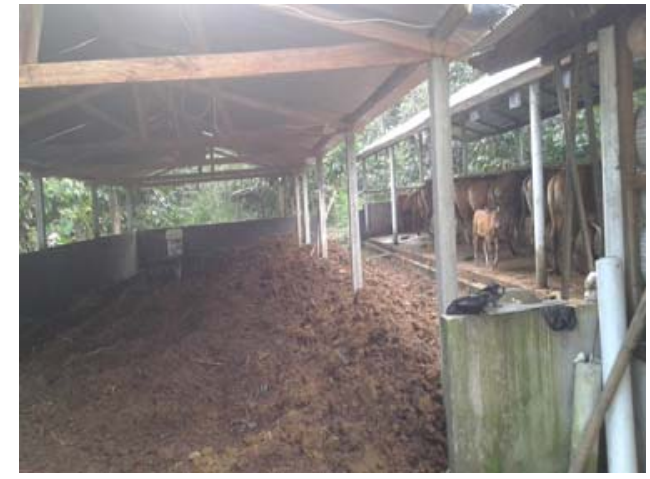

Gambar 3.1. Kotoran sapi bahan pupuk bioorganik

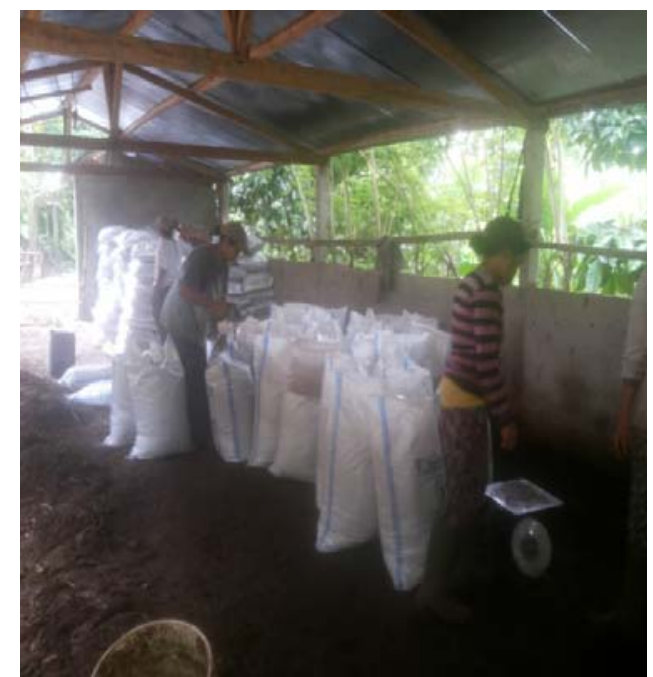

Gambar 2.1 Pelatihan pengemasan pupuk

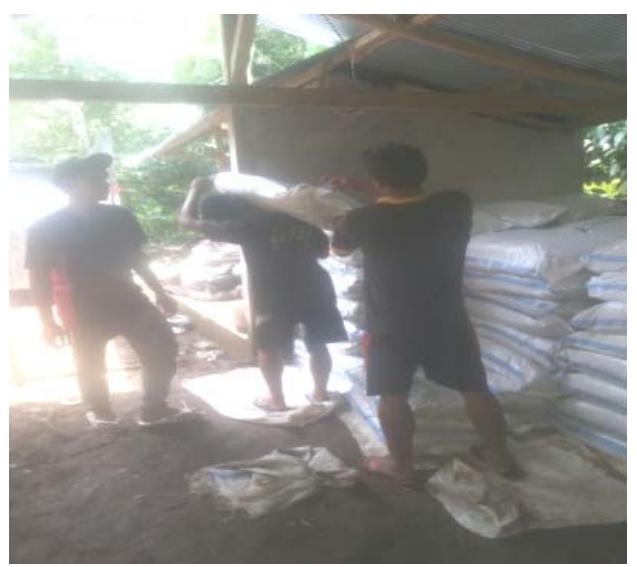

Gambar 3.3. Pupuk bioorganik siap didistribusikan
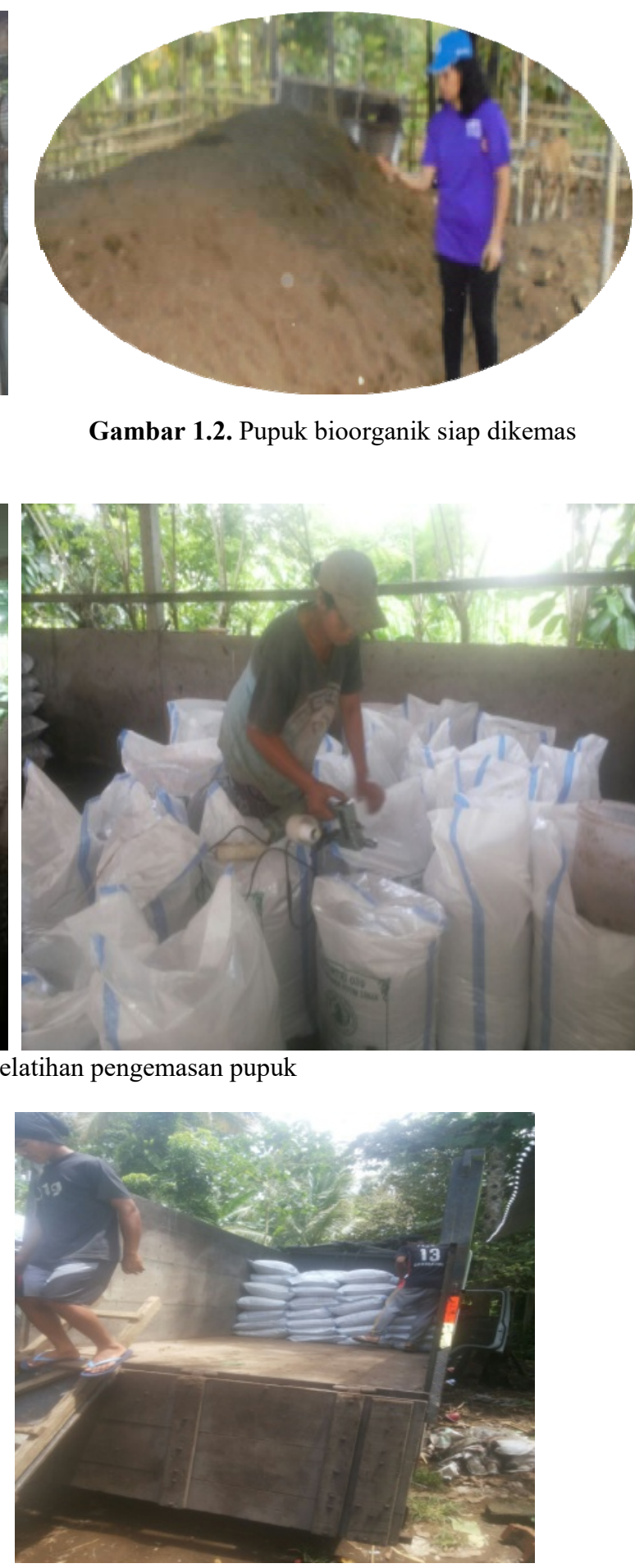

Gambar 1.2. Pupuk bioorganik siap dikemas

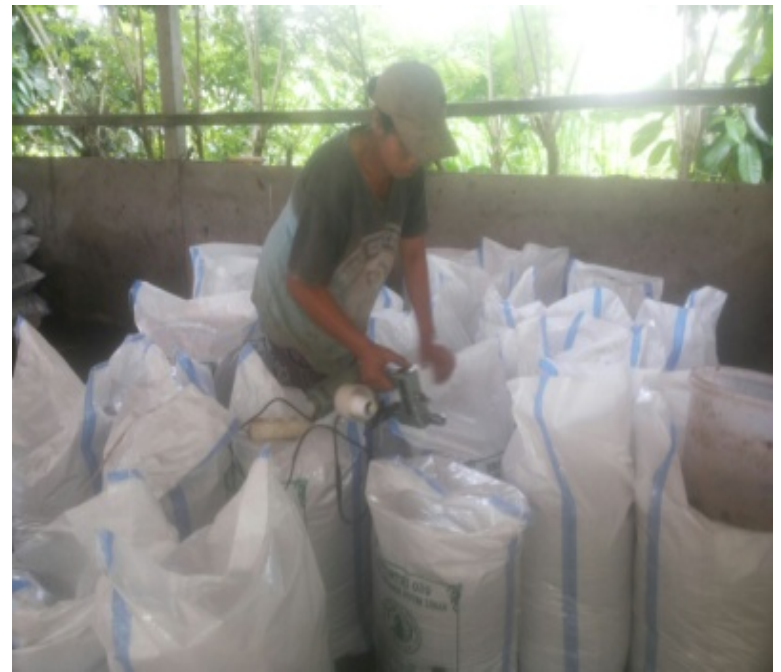

VOLUME 17 NOMOR 2, APRIL 2018 | 55 


\section{UCAPAN TERIMAKASIH}

Penulis menyampaikan terima kasih yang sebesar-besarnya kepada Direktorat Riset dan Pengabdian Masyarakat Kemenristek Dikti atas dana yang diberikan, Ketua Lembaga Penelitian dan Pengabdian kepada Masyarakat Universitas Udayana serta kelompok ternak Pucak Mesari yang telah membantu kelancaran kegiatan ini

\section{DAFTAR PUSTAKA}

Badan Statistik Propinsi Bali. 2012. Bali dalam Angka.

Badan Perencanaan Pembanguanan Kabupaten Gianyar. 2011. Rencana Pembangunan Jangka Menengah Kabupaten Gianyar.

Kartini, N. L. 2000. Pertanian Organik Sebagai Pertanian Masa Depan. Prosiding Seminar Nasional Pengembangan Teknologi Pertanian Dalam Upaya Mendukung Ketahanan Pangan Nasional. Pusat Penelitian Dan Pengembangan Social Ekonomi Pertanian Bekerjasama Dengan Universitas Udayana Denpasar.

Sardina, I K (2014).Kualitas Tanah dan Hasil Sayuran Caisin pada Sistem pertanian Organik dan Konvensional di Kecamatan Baturiti.Kabupaten Tabanan.

Suriadikarta, D. Ardi.,R.D.M. Simanungkalit. 2006. Pupuk Organik dan Pupuk Hayati. Jawa Barat: Balai Besar Penelitian Dan Pengembangan Sumber Daya Lahan Pertanian. Hal 2. ISBN 978-979-9474-575

Sutedjo, R. 2002. Pertanian Organik Menuju Pertanian Alternatif dan Berkelanjutan. Penerbit Kasinius. Yogyakarta. 